\title{
Website Gis-Based Model of Settlement Development in Parepare City, South Sulawesi
}

\author{
Mulyawan ${ }^{1}$, Hayati Sari Hasibuan ${ }^{2}$, Ahyahudin Sodri ${ }^{3}$ \\ \{Mulyawanskom@gmail.com¹, Hayati.hasibuan@ui.ac.id², ahya.sodri@gmail ${ }^{3}$ \} \\ School of Environmental Sciences, Universitas Indonesia \\ Jl. Salemba Raya, No. 4, Jakarta ${ }^{1,2,3}$
}

\begin{abstract}
Population growth has a significant impact on land use for settlements. This article aims to build a model of residential development based on WEBGIS in the city of Parepare.The method used is the spatial analysis of overlay spatial and scoring data using software (GIS). Knowing the public's perception conducted interviews and distributed questionnaires to up to 296 respondents. The results of this study show that the development of settlements towards the suburbs. Forest area fell to 2,971 hectares in 2014, and rice fields were reduced by 837 hectares, and land for settlements increased to 923 hectares in 2015. This WEBGIS model can demonstrate the good distribution of space for the allocation of residential areas. This model is expected to be the benchmark for people who make decisions about the settlement area. This model can be a tool to anticipate the development of settlements in the city of Parepare.
\end{abstract}

Keywords: Model, Settlement, WEBGIS

\section{Introduction}

Population growth continues to increase over time, which has an impact on development [1], population growth is a phenomenon, a potential and a problem of sustainable development. Population growth is linked to the need for continuous space each year [2]. This phenomenon generally occurs in urban areas, where the evolution of land use is very dynamic [3]. Determining the location of land that can be turned into awake land needs to know the type of land use so that excessive land use does not occur [4]. The dynamic evolution of urban land use is very complex influenced by natural, social, economic, cultural, political and legal and other factors.

Today, the use of urban land is radically changing under the general influence of physical geography and the human environment system, affecting all aspects of sustainable urban development [5]. In addition to affecting physical land, the change in land use also affects the social problems of the community, including food security, health insurance, urbanization, loss of biodiversity, migration, preservation of the environment and Others [6]. Land transformation also contributes greatly to the modification of the ecosystem. Bare land, forest or agricultural 
land is reduced due to the development of human habitation which produces a dynamic influence of the spatial patterns of the locality [7].

Parepare City area when viewed from the topography aspect consist of flat to wavy area, with a classification of about $80 \%$ area is the hilly area and the rest of the flat areas with a height of 25 - 500 meters above Sea level (MDPL), with undulating and hilly plateau (88.96\%) With dominant functions for plantation land (18.56\%), forest land (43.04\%) and residential areas ( $1.57 \%$ ), as well as a small piece of land that is flat to ramps (11.04\%) Residential functions $(2.80 \%)$, agriculture $(9.40 \%)$ fishing $(0.24 \%)$. Based on the spatial structure, the city of Parepare is divided into growth centers and municipal services. For the center of growth, the city of Parepare will evolve with the characteristics of the combination of the hilly city and the coastal city, with its main function being the center of the growth of the establishment, commerce and services, as well as the warehousing industry [8].

Table 1. Area Width Based on the Height of the Sea Level of Each District in the City of Parepare

\begin{tabular}{lllllll}
\hline \multirow{2}{*}{ No } & Districts & \multicolumn{5}{c}{ Area of Altitude (Ha) } \\
\cline { 3 - 7 } & & $0-7 \mathrm{~m}$ & $8-25 \mathrm{~m}$ & $26-100 \mathrm{~m}$ & $101-500 \mathrm{~m}$ & $>500 \mathrm{~m}$ \\
\hline & Bacukiki & 154,6 & 776,4 & 2668,78 & 3119,0 & 316,11 \\
& Ujung & 87,16 & 214,78 & 476,64 & 54,40 & - \\
\hline Soreang & 70,84 & 38,6 & 914,64 & 105,92 & -- \\
& Bacukiki Barat & $*$ & $*$ & $*$ & $*$ & $*$ \\
\hline Total & 312,6 & 1029,78 & 5060,06 & 2279,32 & 316,11 \\
\hline \multicolumn{5}{r}{ Source: Main Data of Parepare City 2012 and has been reprocessed }
\end{tabular}

The acceleration of urbanization leads to problems of degradation in an urban environment. The population growth of the city of Parepare every year has increased even if it does not occur significantly. Land conversion is closely linked to the increase in population density.

Table 2. Parepare City Population growth rate for the period 2010-2017

\begin{tabular}{llccccc}
\hline & & \multicolumn{3}{c}{ Total population } & \multicolumn{3}{c}{$\begin{array}{l}\text { Population growth rate } \\
(\%)\end{array}$} \\
\cline { 3 - 7 } No & Districts & 2010 & 2016 & 2017 & $\begin{array}{c}2010- \\
2016\end{array}$ & $\begin{array}{c}2016- \\
2017\end{array}$ \\
\hline 1 & Bacukiki & 14.477 & 17.953 & 18.567 & 3.65 & 3.42 \\
2 & Bacukiki Barat & 39.085 & 42.900 & 43.480 & 1.56 & 1.35 \\
\hline 3 & Ujung & 32.231 & 34.305 & 34.586 & 1.04 & 0.82 \\
4 & Soreang & 43.469 & 45.265 & 45.464 & 0.68 & 0.44 \\
\hline \multicolumn{5}{c}{ Source: BPS Parepare City 2018 reprocessed }
\end{tabular}


A need accurate information on changes in land cover to better understand the changing environment and the interaction between man and the ecosystem [9]. This is done to determine the status of residential land in the present and plan for the future so that the planning of land for residential development in accordance with the potential and existing conditions and the negative impact of land use change can be minimized. After finding the suitability of land for residential development in the town of Pare Pare, will be formulated residential development model. Access to structured data in a vital need to support current and future services to manage existing home and build sustainable cities [10].

This study aims to produce a gis-web application to determine the location of housing and residential election in the town of Pare-pare. System development based website sig residential development to support the detection of changes in land protection and identify potential areas for development of settlements in accordance with the RTRW Parepare. WebGIS is beneficial to stakeholders who have up-to-date spatial information on residential and non-residential areas to guide the strategic implementation of sustainable land use planning and management [11]. So that this application building should facilitate the users, the system is based on an architecture that allows users to access applications via the Internet and to carry out operations on urban data [12].

\section{Methods}

Social context, the population in this study were all household heads of housing users in the Municipality of Parepare. Criteria for respondents are heads of households who have lived in the study site for more than 5 years. The determination of this sample is based on the assumption that the head of the family has a great influence on the behavior of family members, so that it is considered capable of providing responses to adaptability. Calculation of the number of samples determined in this research uses the issac and michael formula approach. Based on data from the Central Statistics Agency (BPS) of Parepare City in 2018, the number of family heads in the Municipality of Parepare is 35.929 households.

Based on the issac and Michael formula and with the consideration that this research applies a significance level of $10 \%$, in order to achieve a confidence level of $90 \%$, the total sample of respondents needed in this research is 268 in general to represent 35927 households. The number of samples will be added by $10 \%$ of the number of samples to anticipate if there is data that is 
not good in research, so the total number of samples in this study amounted to 296 samples. The number of samples of each respondent in each kelurahan was determined proportionally. The sample selection is done by simple random sampling. This is done by selecting the first respondent randomly in a densely populated area in each Sub-district in the City of Parepare, then selecting the next respondent in an interval manner. Population and sample calculations can be seen in Table 3 .

Table 3. Sample Calculation

\begin{tabular}{llcc}
\hline No & Districts & $\begin{array}{c}\text { Population (Total of KK) in } \\
2018\end{array}$ & $\begin{array}{c}\text { Distribution of Samples in Each } \\
\text { District }\end{array}$ \\
\hline 1 & Bacukiki & 4978 & 40 \\
2 & Bacukiki Barat & 11009 & 91 \\
3 & Soreang & 11410 & 93 \\
5 & Ujung & 8712 & 72 \\
\hline \multicolumn{2}{l}{ TOTAL } & 35.929 & 296 \\
\hline
\end{tabular}

\section{Results and Discussions}

GIS Application of Information System Web-based application uses the concept of a single page, this information is available by simply opening a page of the site. Users can access all existing maps on the site of the Map page that is directly connected to the home page. Each group will contain information on the information cards that came from the analysis of factors influencing the determination of the location to build housing and schools.

\subsection{Identification of Community Characteristics}

Based on the age of the respondents, the classification is divided into four groups of age. The most dominant group is the respondents with age less than 31 years old, which is about $49 \%$. The least dominant is the group of respondents with age above 60 years old, which is about $6 \%$. In general, the respondents of this research represent each group of age. The distribution of the respondents for each group are shown in Figure 1. 


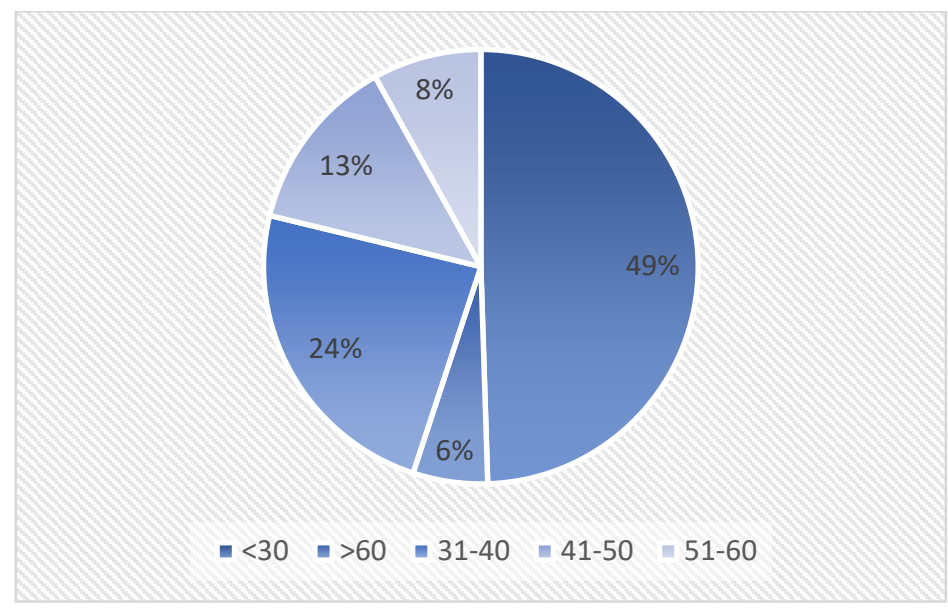

Fig. 1. Distribution of each group of ages

Based on the type of occupation of the respondents, the classification is divided into seven groups of occupation types. The most dominant group is private employee which is about $29 \%$, and the group of entrepreneur has percentage about $25 \%$, while the government employee and other occupation have percentage about $21 \%$ each. The rest is the group of the pensionary have the percentage of $4 \%$. The distribution of the respondents for each group are shown in Figure 2 below.

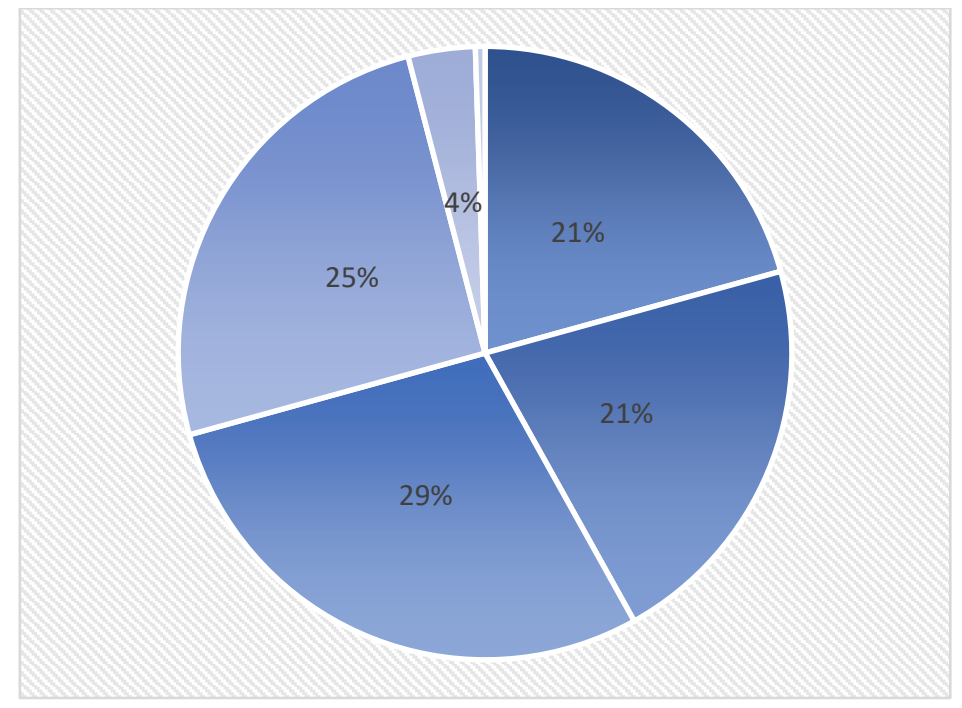

Fig. 2. Proportion of Types of Work 
Based on income level, respondents in this study were divided into five groups. The most represented group of respondents is the income level of Rp. 1,501,000 - Rp. 3,500,000 / month, which corresponds to 34\%. Then, the group with income of Rp. 3,501,000 - Rp. 6,000,000 / month up to 30\%, and the lowest income level groups represented are income groups above Rp. $6,000,000 /$ months, or $10 \%$. Figure 3 shows the distribution of the proportion of respondents by income level.

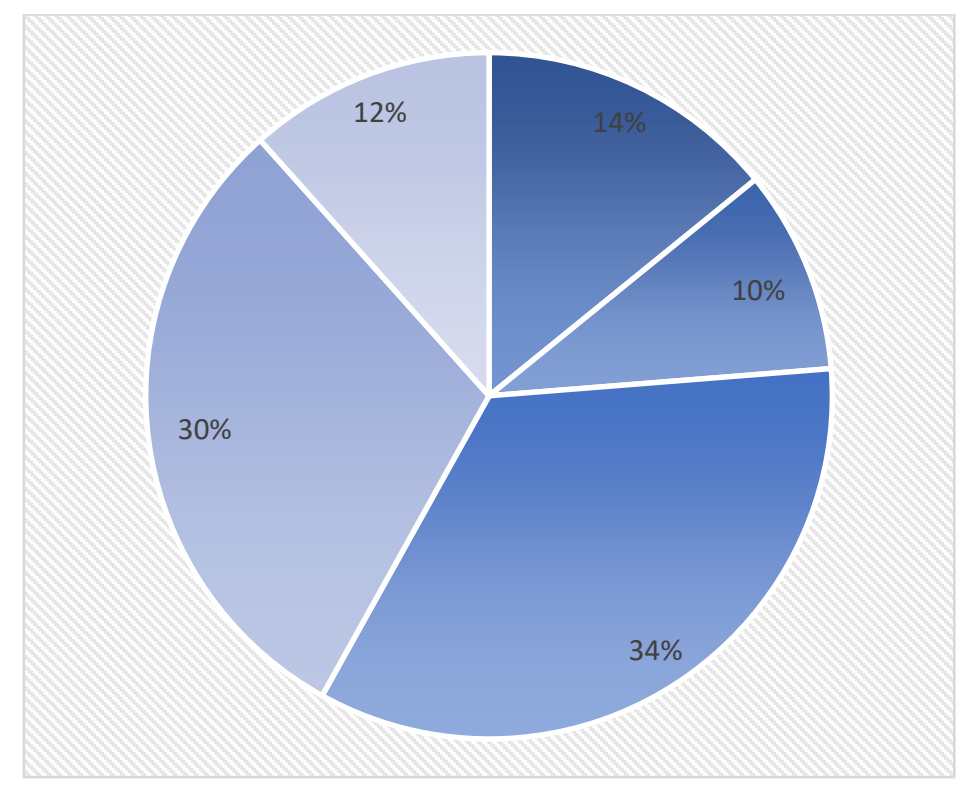

Fig. 3. Proportion of Income Levels

On the basis of reasons to stay, respondents in this study were divided into five groups. The most represented group of respondents was the reason of the original inhabitants of $68 \%$, then the next group was the reason to participate to the parents of $20 \%$, the least represented group being the group with the reason to join a husband of $4 \%$. Figure 4 shows the distribution of the proportion of reasons for life in a locality. 


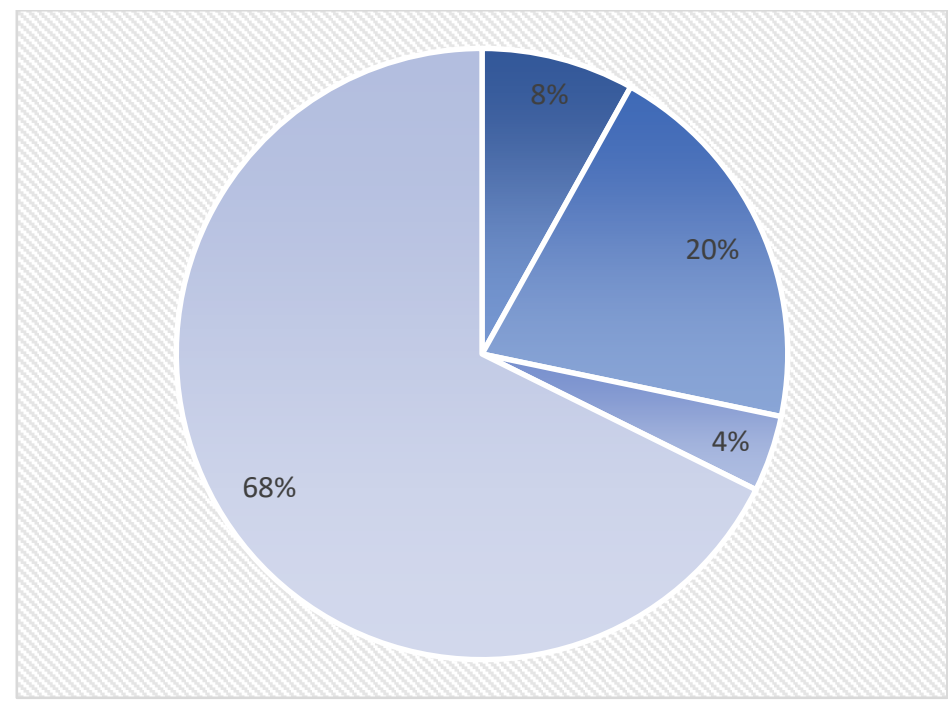

Fig. 4. Proportion of Reasons for Staying

Based on residency status, respondents to this study were divided into four groups: selfowners, parent owners, hitch-hiking, lease / contract. The group of respondents with the status of their own residence is the group with the highest number of respondents, $47 \%$. In addition, followed by the parents' group respondents with $44 \%$, the lease / contract respondents group with a figure of $6 \%$ and the constituency group respondents are the smallest group of respondents with a number of $3 \%$. Figure 5 shows the distribution of the proportion of respondents by length of stay.

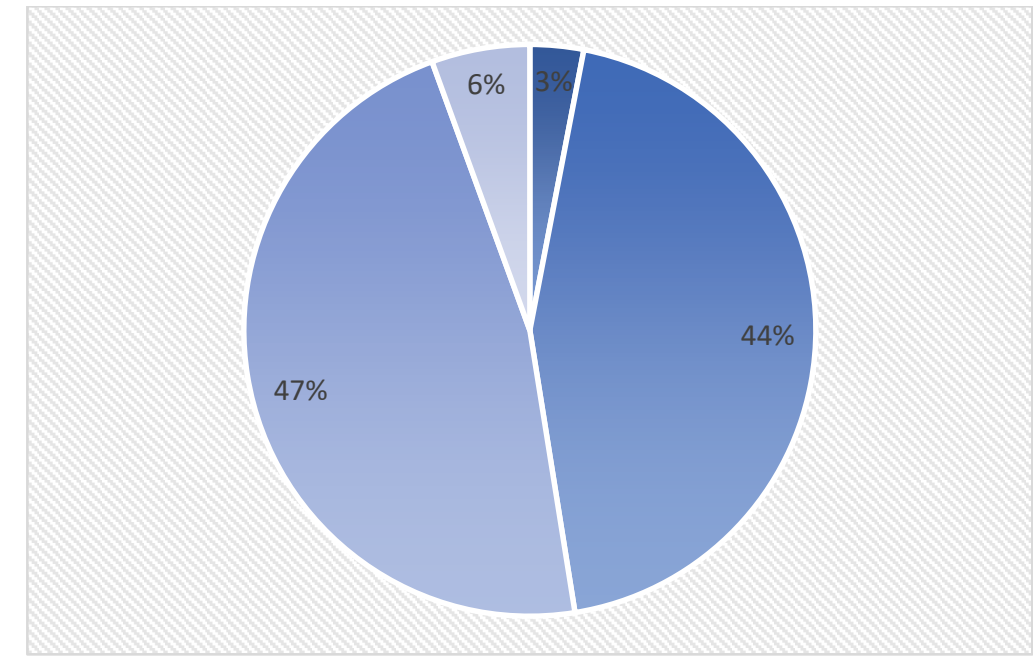

Fig. 5. Proportion of residence status 
Based on the number of residents in the house, respondents to this study were divided into four groups, namely 1 to 3 people, 4 to 6 people, 7 to 9 people and more than 9 people. The group of respondents with the number of occupants of the home 4-6 persons in the group with the most respondents is $59 \%$. Then, followed by respondents in the 1 to 3 resident group of $27 \%$, the group of respondents was made up of 7 to 9 people with $9 \%$ and respondents in the group of residents of more than 9 people were the group of respondents the smallest with a figure of $5 \%$ Figure 6 shows the distribution of the proportion of respondents by the number of residents.

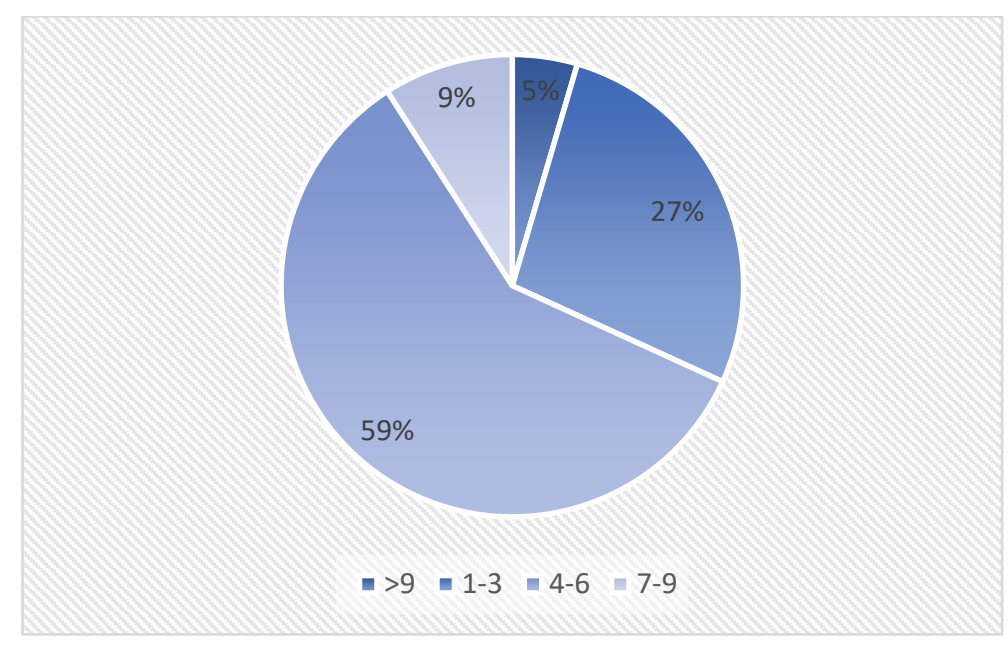

Fig. 6. Proportion of Number of House Residents

Based on building age, respondents to this study were divided into three groups, namely less than 10 years, 10-20 years and over 20 years. The group of respondents with a total building age greater than 20 is the one with the highest number of respondents, at $48 \%$. In addition, respondents from groups under the age of 10 and respondent groups aged 10 to 20 each receive $26 \%$. Figure 7 shows the distribution of age proportions of buildings. 


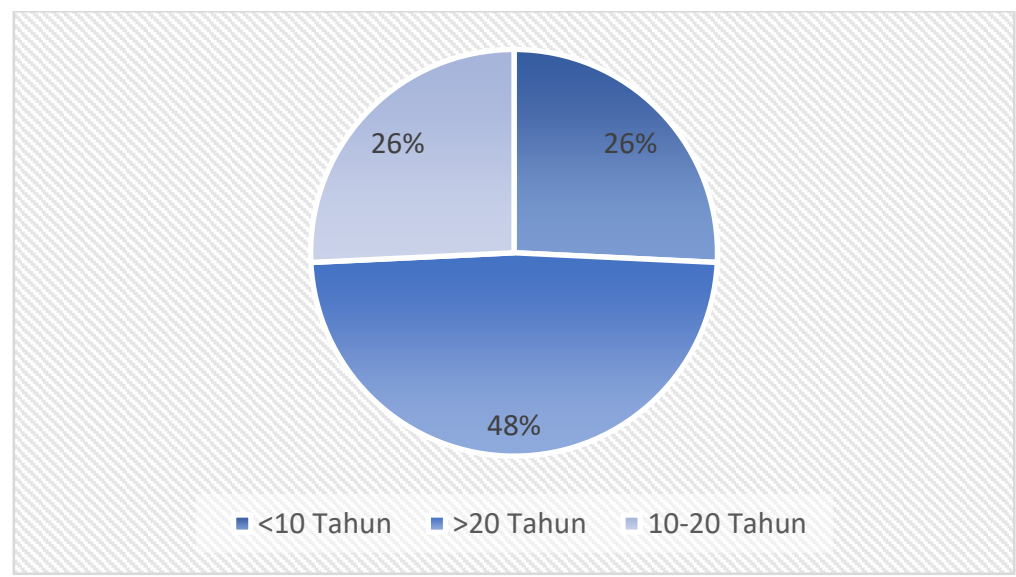

Fig. 7. Proportion of Building Age

Based on the building area, the respondents to this study were divided into five groups, namely less than $21 \mathrm{~m}^{2}, 21 \mathrm{~m}^{2}, 36 \mathrm{~m}^{2}, 45 \mathrm{~m}^{2}$, more than $45 \mathrm{~m}^{2}$. The group of respondents with a building area of more than $45 \mathrm{~m}^{2}$ is the one with the largest number of respondents, $18 \%$. In addition, followed by respondents from the building area of $45 \mathrm{~m}^{2}$ to $21 \%$, then the group with an area of $36 \mathrm{~m}^{2}$ to $20 \%$. The group with a building area of $21 \mathrm{~m}^{2}$ is $12 \%$ and the group of respondents is less $21 \mathrm{~m}^{2} 6 \%$. The distribution of the proportion of building area is shown in Figure 8 .

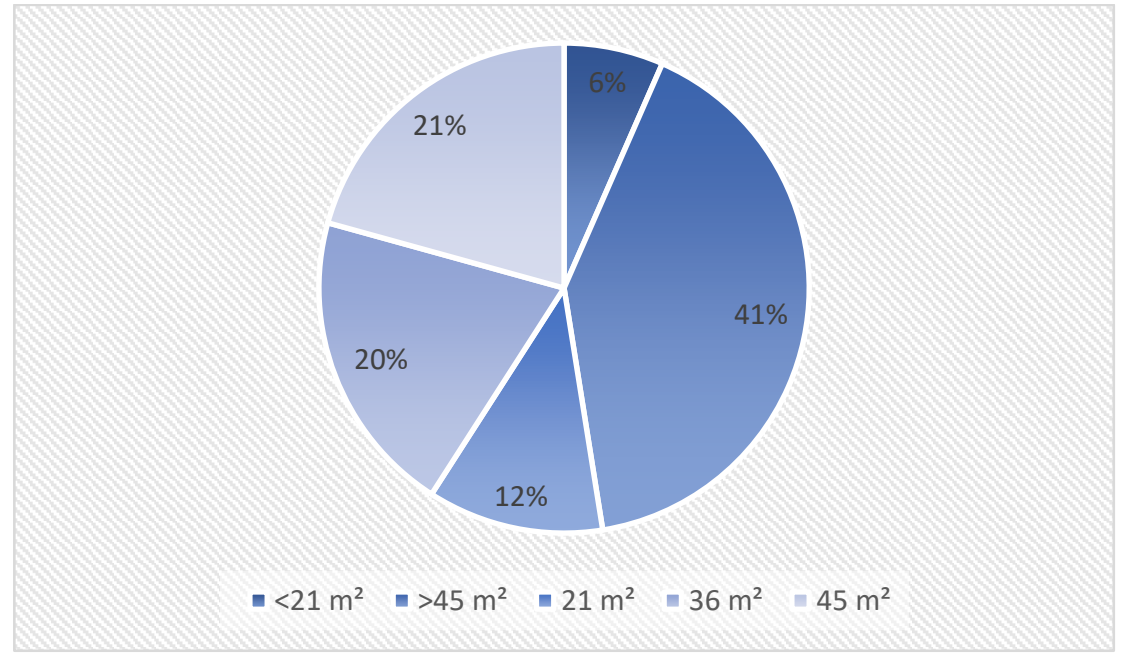

Fig. 8. Proportion of Building Area 


\subsection{Identification of Factors Influencing Communities to Choose Residential Locations}

The formulation of the factors that influence the community when choosing a site for the environment is of particular relevance to existing empirical conditions. For the formulation of the factors that influence the community of the location of settlements in the city of Parepare, we can mention:

\subsubsection{Physical Factor}

Slope is an important factor as it is closely linked to vulnerability to disasters and the ability of a settlement to develop its territory. The results of this study indicate that existing settlements occupy the land in accordance with land suitability requirements, such as $0-20 \%$ slope, while in Ujung District the area with higher slope at $20 \%$ is still a settlement area. The majority of respondents in this study showed a neutral direction with a figure of $49 \%, 26 \%$ of the population said they chose to settle on a slope of more than $20 \%$. Figure 9 shows the proportion of slope factors.

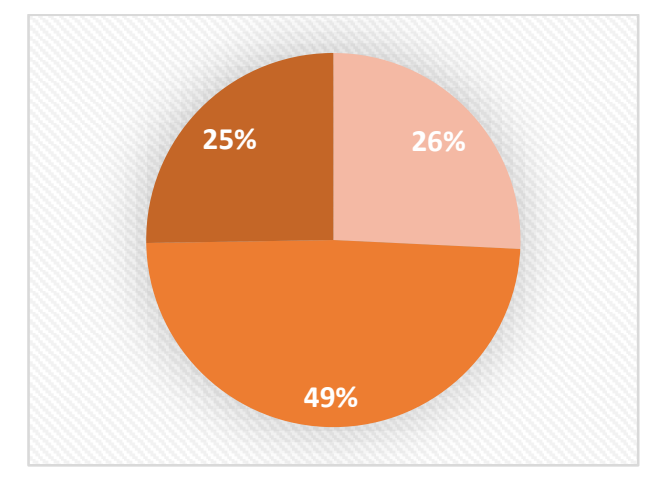

Fig. 9. Proportion of Slope Factor

Noson (2000) defines vulnerability as a specific condition or characteristic leading to increased damage, loss and loss resulting from a disaster, based on characteristics such as the type of building material, demographics, and geographic location. Based on the results of the study, it appears that the majority of respondents indicated a positive number of lands chosen for settlements not located in disaster-prone areas. $80 \%$ of those surveyed said that settlement construction should avoid areas prone to disasters. While $5 \%$ of the population said they chose a location for settlements in disaster-prone areas. Figure 10 shows the proportion of disaster risk factors. 


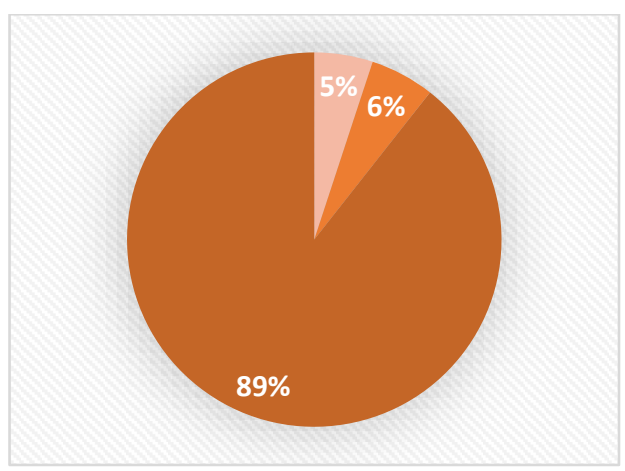

Fig. 10. Proportion of Disaster Prone Factors

\subsubsection{Accessibility Factor}

The accessibility factors are the convenience of the mall. The conclusions of this study are that the mall in question is a commercial center in the form of a market. Close access to markets is an important factor in meeting basic daily needs. The results of this study indicate a positive level of $71 \%$, which indicates that the community determines the location of homes close to the market, while $4 \%$ of those surveyed said they chose land to settle not close to the market. market. Shopping malls in the form of a market are not evenly distributed in the study area, which is provided by the local government and is used to meet the daily needs of the inhabitants of the city. The location of this study has a wholesale market in each district.

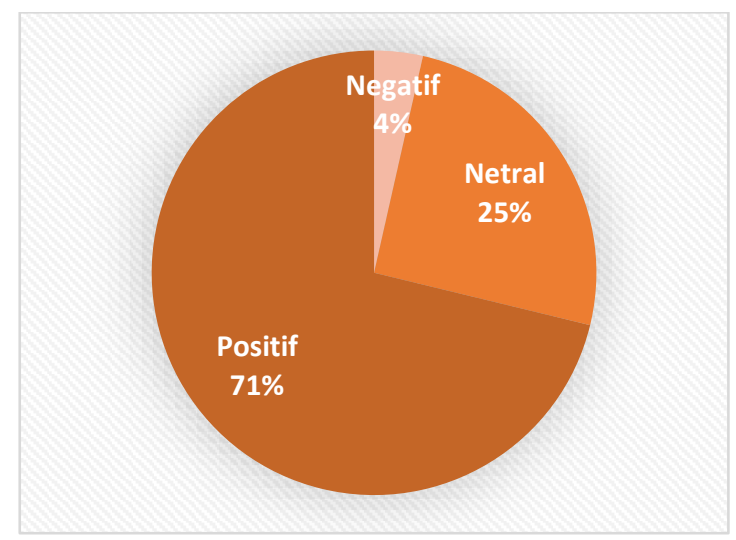

Fig. 11. Proportion of Accessibility Factors

\subsubsection{Clean Water Availability Factors}

The supply of drinking water is one of the main needs of the residential environment. In fact, $80 \%$ of the inhabitants will choose the location of agglomerations with access to safe water and 
$4 \%$ will choose establishments regardless of the availability of drinking water. Figure 12 illustrates the proportion of water availability.

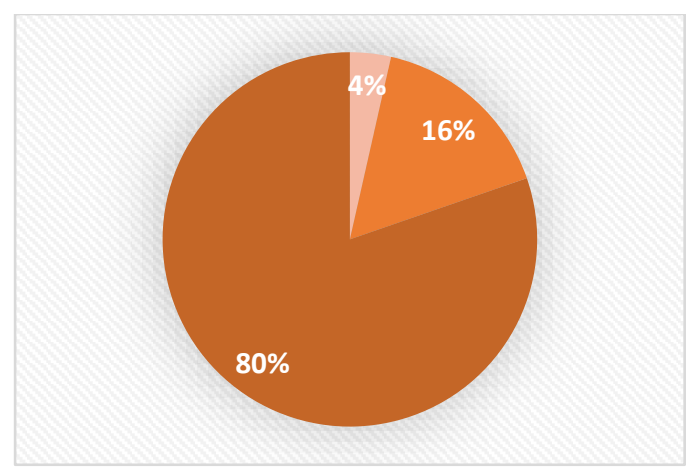

Fig. 12. Proportion of Clean Water Supply Factors

\subsubsection{Land Price Factors}

The existence of residential areas in the downtown and downtown has variable land prices that are influenced by the value of the land. The existence of residential land in the downtown core is in high demand while land remains, there is a shortage of land in the downtown core, so the land has value and impact on the land. higher land prices (Khoiriyah et al 2017). The results of this study indicate that $70 \%$ of people choose economic land prices.

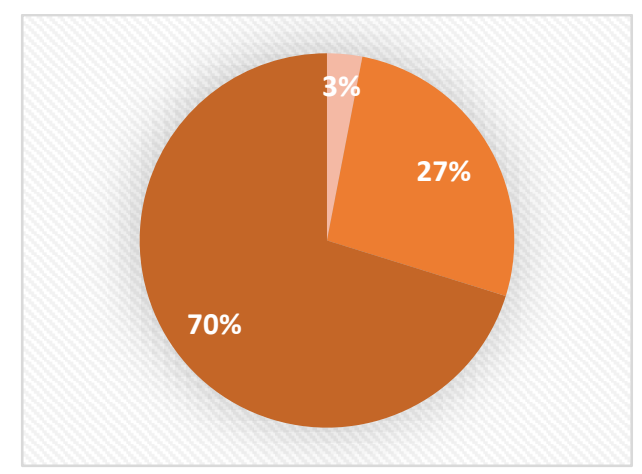

Fig. 13. Proportion of Land Price Factor

\subsection{Priority Area Regional Development Housing and Settlements Under General Spatial}

\section{Plan (RTRW) Parepare}

RTRW is fundamental to provide a recommendation to direct the use of space, including also for residential areas, it is necessary to analyze the alignment between the analysis of the relevance of the regulation area in Parepare RTRW cities which aims to determine the spread of existing settlements between land and areas with the potential for institutions and home of 
analytical results. spatial maps used, which is the city RTRW 2010-2030 Parepare. Figure 14 is the map land use of parepare city.

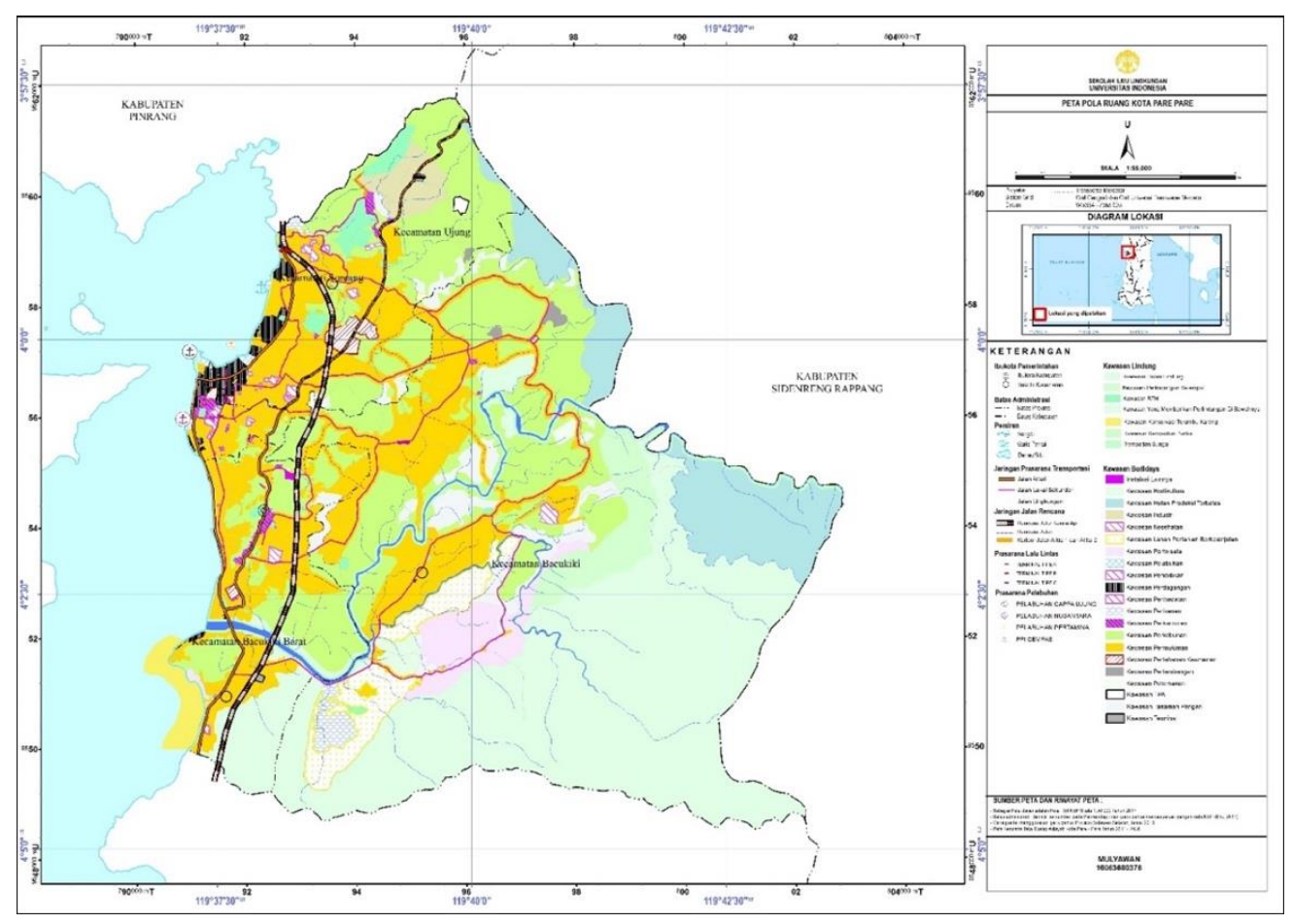

Fig. 14. The Map of land use Parepare City

\subsection{Opera-Interface System Website Design Development Geographic housing}

Based on the results of the discussion on the analysis of the influence of institutional development on planning planning for the city of Parepare and the factors that influence the choice of lands to be development of institutions is the solution. This situation affects residents' growing need for housing, transportation facilities and infrastructure, and other public amenities. Physical development and urban infrastructure in the form of housing development as a place to live. The physical construction activities of the agglomerations and urban infrastructure in the city of Parepare must support the RTRW as well as community access to information if it will build homes in the residential area. 


\subsubsection{Preparation of the website interface design}

The web application interface is built using Macromedia Dreamweaver. In general, the navigation structure of web applications is composed of menus, namely the home menu, profiles, maps and information. These menus can be directly connected to other pages without going through the main page. The navigation structure used in Web applications uses mixed types (a combination of nonlinear and hierarchical navigation structures). In the map menu, a link can be connected to the search map page. In the search map page, navigation makes it easy for users to use web applications. The rationale for the website features is presented in Table 4 .

Table 4. Justificasi Fitur Website

\begin{tabular}{|c|c|c|}
\hline NO & FITUR & DESCRIPTION \\
\hline 1 & Digital Map Service (MAPS) & $\begin{array}{l}\text { Digital map services use the Google Maps Application } \\
\text { Programming Interface (API) }\end{array}$ \\
\hline 2 & Tagging & $\begin{array}{l}\text { Support for marking new coordinates or locations into a } \\
\text { particular node type }\end{array}$ \\
\hline 3 & $\begin{array}{l}\text { Categories / filtration based on } \\
\text { node type }\end{array}$ & $\begin{array}{l}\text { Filtering certain types of nodes to display similar nodes, } \\
\text { this feature is needed if the service that is owned has a } \\
\text { variety of items. }\end{array}$ \\
\hline 4 & List of alternative nearest node & $\begin{array}{l}\text { Each node can display alternative node lists with the closest } \\
\text { distance }\end{array}$ \\
\hline 6 & $\begin{array}{l}\text { Distribution of vertices of each } \\
\text { region }\end{array}$ & Shows the number of node distributions for each region/city \\
\hline 8 & Node description & $\begin{array}{l}\text { Displays complete information of each node, for example } \\
\text { the name, }\end{array}$ \\
\hline 9 & List of available residential areas & Displays a selection of residential area types \\
\hline 12 & Coordinate (Latitude \& Longitude) & $\begin{array}{l}\text { Displays information on the location of coordinates in the } \\
\text { form of latitude and longitude }\end{array}$ \\
\hline 13 & Search Feature & Supports node search by name \\
\hline 14 & Mobile friendly (responsive web) & $\begin{array}{l}\text { The interface is responsive so it can be used on various } \\
\text { types of desktop and smartphone devices with high display } \\
\text { accuracy }\end{array}$ \\
\hline 15 & Administrator Dasboard & $\begin{array}{l}\text { Control panel page to update content, for example add, } \\
\text { change or delete or adjust website content. }\end{array}$ \\
\hline 16 & E-mail Domain & $\begin{array}{l}\text { Administrators can use email according to the domain } \\
\text { extension used by Exp. admin@ domainname.institution }\end{array}$ \\
\hline 17 & Header and Footer & Contains the signature of the institution that owns the portal \\
\hline
\end{tabular}


Card used in the web-gis is a land cover maps overlay, forest area and density of the population. Experiments, the map display is quite good, informative and was equipped with the functions of "basic operational tool" (basic tools) for the information system in the form of a card or depending magnification (zoom), movement (pan), map scale changes (scale), etc. Detailed information can be displayed directly by clicking on the data / information polygon you want to display, or information based on polygons district to district, as well as land use polygons for land use maps and card plans land use. Users can also set the map layer you want to view by clicking the map layer selection option on the right side of the displayed map image.

Figure 15 is GIS Web Design Interface and housing development regulations Parepare

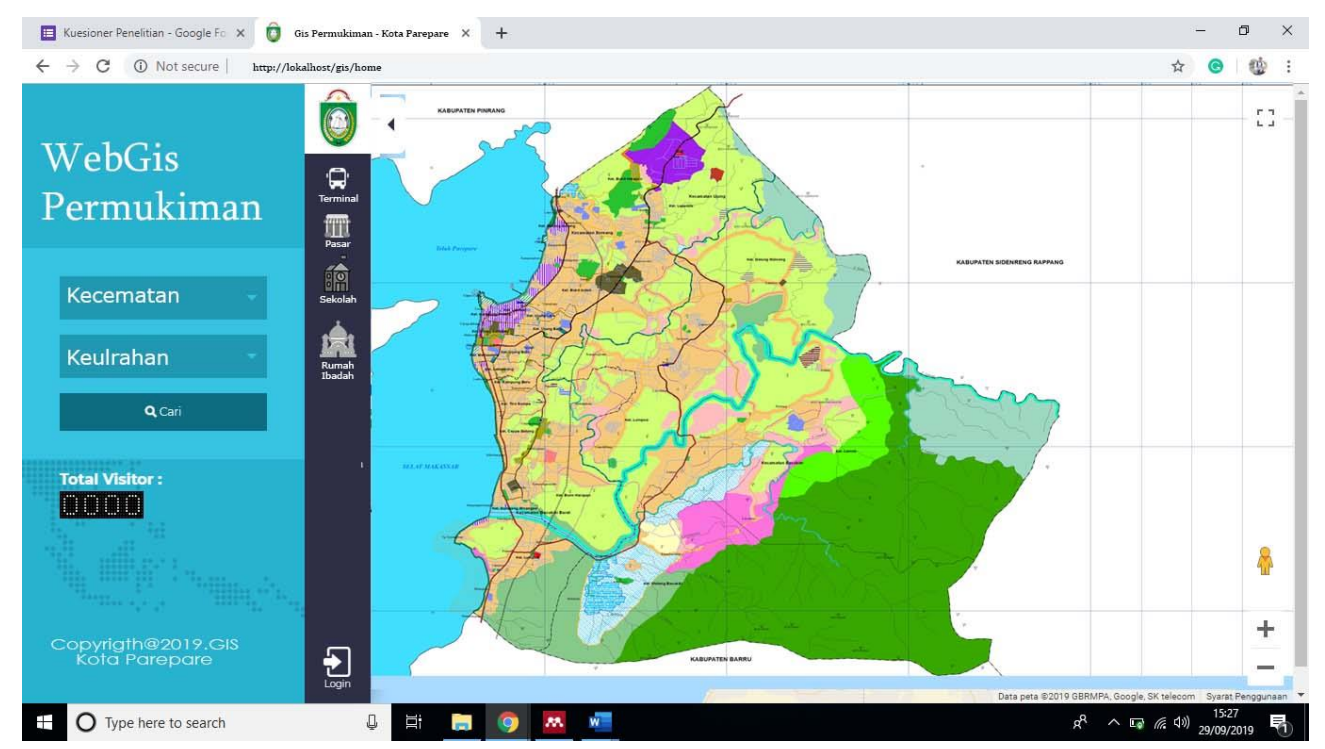

Fig. 15. GIS Web Design Interface and housing development regulations Parepare

This research is in line with [13] WebSIG displays an architecture consisting of three levels of architecture with customers or servers. On the client side it can be a web browser, while on the server side it consists of a web server, webSIG software and a database. The application to be built is a model for controlling settlement development in the City of Parepare, in line with [14] that this WebSIG must be developed by government agencies. 


\section{Conclusion}

It was concluded that the results of the application of information systems GIS Web is instructive to describe the factors that people in the construction of housing and schools in each district. The information is grouped into six factors: slope, disaster areas, accessibility, distance from the center of commercial facilities and public services, the availability of water, land conversion the system must be tested on a limited basis with the participation of candidates potential users of information systems, which in this case is the decision-makers at local level.

Acknowledgements. This research is funded by the grant Indexed International publication for the final master's project The students of the Department of Research and Community Services, University of Indonesia Number NKB 1021 / UN2 / R3.1 / HKP. 05.00 / 2019.

\section{References}

[1] Yunus, S.H., (2008). Dinamika Wilayah Peri Urban Determinasi Masa Depan Kota. Pustaka Pelajar. Yogyakarta.

[2] George, H. 2006. Progress \& Poverty. London: Elibron Classics.

[3] Pribadi, D., Shiddiq, D., dan Ermyanila, M. 2006. Model Perubahan Tutupan Lahan dan Faktorfaktor yang Mempengaruhinnya. Jurnal Teknologi Lingkungan BPPT, 3(1): 77-91

[4] Yoga Kencana Nugraha, Arief Laila Nugraha, Arwan Putra Wijaya, (2014). Pemanfaatan sig untuk menentukan lokasi potensial Pengembangan kawasan perumahan dan permukiman (Studi Kasus Kabupaten Boyolali), Jurnal Geodesi Undip, Volume 3, Nomor 4, 2014.

[5] Wang S Q, Zheng X Q and Zang X B. (2012). Accuracy Assessment of Land Use Change Simulation Based on Markov-Cellular Automata Model, Procedia Environmental Sciencess

[6] Mendoza ME, Granados EL, Geneletti D, Perez-Salicrup DR, Salinas V. 2011. Analysing Land Cover and Land Use Change Processes at Watershed Level: A Multitemporal Study in The Lake Cuitzeo Watershed Mexico (1975-2003). Applied Geography. 31(1):237-250.

[7] Reshmi Shaw., Arijit Das., (2018). Identifying peri-urban growth in small and medium towns using GIS and remote sensing technique: A case study of English Bazar Urban Agglomeration, West Bengal, India. The Egyptian Journal of Remote Sensing and Space Sciences 21 (2018) 159-172.

[8] Oki Oktariadi, (2007). Optimalisasi Pemanfaatan Ruang Kota Pare-Pare Berdasarkan Aspek Geologi Lingkungan, Kolokium Hasil Kegiatan Tahun 2006 Pusat Lingkungan Geologi, Bandung.

[9] Hussain, Masroor, Dongmei Chen, Angela Cheng, Hui Wei, and David Stanley. 2013. "Change Detection from Remotely Sensed Images: From Pixel-Based to Object-Based Approaches." ISPRS Journal of Photogrammetry and Remote Sensing 80:91-106.

[10] M. Bilal, L. O. Oyedele, J. Qadir, K. Munir, S. O. Ajayi, O. O. Akinade, H. A. Owolabi, H. A. Alaka, and M. Pasha, (2016). "Big Data in the construction industry: A review of present status, opportunities, and future trends," Adv. Eng. Informatics, vol. 30, no. 3, pp. 500-521, Aug.

[11] Jayakumar Kanaan And Malarvannan S, 2015. A WebGIS based Decision Support System for Land Use and Land Cover Changes: A Case Study of Tiruvallur Block, Tiruvallur District, Tamil Nadu, Geo-Ref Information Services-USA, List B of Scientific Journals, Poland, Directory of Research Journals.

[12] Cheikh H.T.Cherif Ndiaye,Ndeye Fatou Ngom, Oumar NIANG, ABabacar Fall, 2018. Web based GIS for multicriteria vulnerability classification and prediction in urban area: the case of Yeumbeul (Dakar), International Conference on Smart Cities and Communities (SCCIC). 
[13] Helali, H., (2001). Design and Implementation of a Web GIS for the City of Tehran. MSc Thesis, Department of Geodesy And Geomatics Engineering K.N. Toosi University of Technology, Tehran, Iran.

[14] Li, S., S., D., \& Veenendaal, B., (2011). Advances in Web-based GIS, Mapping Services and Applications. London: CRC Press/Balkema. 